\title{
Profile of alanine aminotransferase and hepatic iron accumulation in thalassemic patients with or without anti-hepatitis $\mathrm{C}$ virus
}

\author{
Purnamawati SP, MD; Pamela Kartoyo, MD; Imral Chair, MD; Julfina Bisanto, MD; Hanifah \\ Oswari, MD
}

\begin{abstract}
Background Repeated blood transfusions in thalassemic patients cause iron accumulation in tissues and might impair organ function. Other peril of blood transfusion is hepatitis $C$ virus infection. Objectives This study aimed to find out the proportion of increased alanine aminotransferase (ALT), increased transferrin saturation (TS), and positive anti hepatitis C virus (anti-HCV) among thalassemic patients and to get the profile of ALT among thalassemic patients who have increased TS and positive anti-HCV.

Methods This cross-sectional descriptive study was conducted on $\beta$ - and $\beta$-HbE-thalassemic patients at the Thalassemia Outpatient Clinic, Department of Child Health, Medical School, University of Indonesia-Cipto Mangunkusumo Hospital in May 2002.

Results Subjects were 57 homozygous $\beta$-thalassemic and $33 \beta$ $\mathrm{HbE}$-thalassemic patients. No one had regular desferoxamine or history of splenectomy. Proportions of increased ALT, TS, and positive anti-HCV were $76 \%, 78 \%$, and $6 \%$, respectively. Duration of illness, total volume of packed red cell (PRC) transfusions, TS level, and positive anti-HCV seemed to have role in the increased proportion of subjects with increased ALT, whereas duration of illness and total volume of PRC seemed to have role in the increased TS. Conclusion Factors that seem to have a role in the increased proportion of subjects who had increased ALT and TS were (1) duration of illness, total volume of PRC transfusion, TS, and positive anti-HCV; 2) duration of illness and total volume of PRC transfusion, respectively [Paediatr Indones 2004;44:85-89].
\end{abstract}

Keywords: alanine aminotransferase, hepatic iron accumulation, transferrin saturation, anti hepatitis $\mathrm{C}$ virus, thalassemia

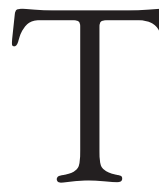

halassemia is a group of congenital anomaly with anemia as its major symptom. Children who suffer from this disease need a life-long repeated blood transfusion to maintain their hemoglobin level around $12 \mathrm{~g} / \mathrm{dL}$, but unfortunately those will cause an accumulation of iron in various tissues accompanied by an increased serum iron level. The accumulation of iron, which might cause damage to the parenchyma of the tissues and organ function impairment, is known as hemochromatosis. ${ }^{1-4}$ One of the organs that is impaired by the iron accumulation is the liver. ${ }^{5}$ Fibrosis and cirrhosis are the major manifestation of chronic iron accumulation in the liver. The development of fibrosis and cirrhosis is assumed to be caused by peroxidation of hepatocellu-lary lipid that causes cellular damage and or death. ${ }^{6-8}$ At advanced stage, the liver iron accumulation might cause hepatocellular carcinoma. ${ }^{6}$

Another peril of blood transfusions to thalassemic patients is hepatitis $\mathrm{C}$ virus (HCV) infection. Hepatitis $C$ virus is the major cause of post-transfusion hepatitis. ${ }^{9}$ Liver cells that contain the virus tend to accumulate iron. ${ }^{10,11}$ In the condition of iron accumulation and chronic viral hepatitis, there is an

From the Department of Child Health, Medical School, University of Indonesia, Cipto Mangunkusumo Hospital, Jakarta

Reprint requests to: Purnamawati SP, MD, Department of Child Health, Medical School, University of Indonesia, Jakarta, Indonesia. Tel. 62-213915712; Fax. 021-3907743. 
increase of serum iron level, transferrin saturation, and ferritin level.4,10-14 Transferrin saturation examination is considered effective to prove early hemochromatosis.4,12-14 To judge the extend of liver cells damage caused by iron accumulation, we need to assess the serum transaminase enzymes [aspartate aminotransferase (AST) and alanine aminotransferase (ALT)]. Iron accumulation and hepatitis C virus infection cause an increase of transaminase enzymes level. $6,11,15-20$

This study aimed to find out the proportion of increased ALT, transferrin saturation, and positive anti-HCV among thalassemic patients, and to get the profile of ALT among thalassemic patients who have increased transferrin saturation and positive anti$\mathrm{HCV}$.

\section{Methods}

This cross sectional descriptive study was conducted on $\beta$ - and $\beta-\mathrm{HbE}$-thalassemic patients at the Thalassemia Outpatient Clinic, Department of Child Health, Medical School, University of Indonesia, Cipto Mangunkusumo Hospital in May 2002.

Inclusion criteria were patients who had homozygous- $\beta$ - or $\beta$-HbE-thalassemia, had gotten total volume of packed red cells (PRC) transfusions of 5 liter or more since 1996, were not obese, did not drink alcohol, were not on certain medication (penicillin, ciprofloxacin, nitrofurantoin, ketoconazole, fluconazole, isoniazide, phenytoin, carbamazepine, non steroid anti inflamation, Chinese herbal medication, anabolic steroid, cocaine, amphetamine), did not suffer from myositis or DMP, and had permission from the parents.

We took data about the subjects' identity, sex, age of diagnosis, kind of thalassemia, history of transfusion, desferoxamine consumption, and history of splenectomy. The subjects were assessed for serum iron level (SI) and total iron binding capacity (TIBC), level of ALT, and antiHCV using Entebe dipstick. Transferrin saturation (\%) was calculated from percentage of SI divided by TIBC. It was considered increased (= iron accumulation) if the result was $55 \%$ or more. 12,13 Level of ALT was considered increased if it was more than $40 \mathrm{U} / \mathrm{L} .{ }^{19}$

\section{Results}

The study was conducted on $90 \beta$-thalassemic patients consisting of 57 homozygous $-\beta$-thalassemic and $33 \beta$ $\mathrm{HbE}$-thalassemic patients. No study subject got regular desferoxamine and no one had undergone splenectomy. The subjects consisted of 41 boys and 49 girls, aged $3-13$ years (median 7 year-old). Duration of illness ranged between 1.5 and 6.5 years (median 4.5 years) and total volume of transfused PRC were 5,080-33,900 mL (median 11,397.5 mL).

Increased ALT was found in 68 subjects (76\%). Table 1 shows that the proportion of increased ALT increased in relevance with duration of illness (0-5 years, $44 / 65 ;>5$ years, $24 / 25)$ and total volume of PRC transfusions (5,000-11,397.5 mL, 33/45; $>11,397.5 \mathrm{~mL}, 35 / 45)$.

Increased TS was found in 70 subjects (78\%). Table 2 shows that the proportion of subjects who had increased TS was increased in relevance with duration of illness $(0-5$ years, $45 / 65$; $>5$ years, $25 / 25)$, total volume of PRC transfusions $(5,000-11,397.5 \mathrm{~mL}$, $33 / 45$; >11,397.5 mL, 37/45), but not with positive anti-HCV (negative anti-HCV, 66/84; positive anti$\mathrm{HCV}, 4 / 6)$.

Positive anti-HCV was found in 6 subjects (6\%). Table 3 shows that the proportion of subjects with positive anti-HCV did not increase in relevance with duration of illness $(0-5$ years, $4 / 65 ;>5$ years, $2 / 25)$ and total volume of PRC transfusions (5,000-11,397.5 $\mathrm{mL}, 5 / 45$; >11,397.5 mL, 1/25).

The proportion of subjects who had increased ALT increased among subjects who had increased TS (normal TS, 1/20; increased TS, 67/70) and among subjects who were positive for anti-HCV (negative anti-HCV, 63/84; positive anti-HCV, 5/6). This is presented in Table 4.

Table 1. Profile of Alt in relevance with duration OF ILLNESS AND TOTAL VOLUME OF PRC TRANSFUSIONS

\begin{tabular}{lcll}
\hline & & ALT & Total \\
\cline { 2 - 3 } & Normal & Increased & \\
\hline Duration of illness (years) & 21 & 44 & 65 \\
$0-5$ & 1 & 24 & 25 \\
$>5$ & 12 & 33 & 45 \\
Total PRC $(\mathbf{m L})$ & 10 & 35 & 45 \\
$5,000-11,397.5$ & & & \\
$>11,397.5$ & &
\end{tabular}


Purnamawati SP, et al: Alanine aminotransferase and hepatic iron accumulation in thalassemic patients

Table 2. Profile of transferrin saturation in RELEVANCE WITH DURATION OF ILLNESS, TOTAL PRC, AND ANTI-HCV

\begin{tabular}{lccc}
\hline & \multicolumn{2}{c}{ Transferrin saturation } & Total \\
\cline { 2 - 3 } & Normal & Increased & \\
\hline $\begin{array}{l}\text { Duration of illness } \\
0-5\end{array}$ & 20 & & \\
$>5$ & - & 45 & 65 \\
Total PRC $(\mathbf{m L})$ & & 25 & 25 \\
$5,000-11,397.5$ & 12 & 33 & 45 \\
$>11,397.5$ & 8 & 37 & 45 \\
Anti HCV & 18 & 66 & 84 \\
Negative & 2 & 4 & 6 \\
Positive & & & \\
\hline
\end{tabular}

Table 3. Profile of anti-HCV in Relevance with DURATION OF ILLNESS AND TOTAL PRC

\begin{tabular}{lcll}
\hline \multicolumn{1}{c}{} & \multicolumn{1}{c}{ Anti-HCV } & Total & \\
\cline { 2 - 3 } & Negative & Positive & \\
\cline { 1 - 2 } Duration of illness (years) & & \\
$0-5$ & 61 & 4 & 65 \\
$>5$ & 23 & 2 & 25 \\
Total PRC $(\mathrm{mL})$ & & & \\
$5,000-11,397.5$ & 40 & 5 & 45 \\
$>11,397.5$ & 44 & 1 & 45 \\
\hline
\end{tabular}

Table 4. Profile of alt in relevance with TRANSFERRIN SATURATION AND ANTI-HCV

\begin{tabular}{llll}
\hline & \multicolumn{2}{l}{ ALT } & Total \\
\cline { 2 - 3 } & Normal & Increased & \\
\hline Transferrin saturation & 19 & 1 & 20 \\
Normal & 19 & 67 & 70 \\
Increased & 3 & & \\
Anti-HCV & 21 & 63 & 84 \\
Negative & 1 & 5 & 6 \\
Positive & & &
\end{tabular}

\section{Discussion}

This study found almost equal numbers of boys and girls (ratio 1:1.2). Jaiswal et $\mathrm{al}^{19}$ in India found more boys than girls with a ratio of 1.8:1. A relatively wide range of age (313 years old) in this study was the consequence of the inclusion of $\beta$-HbE-thalassemics. Beta-HbE-thalassemics are usually diagnosed and get the first transfusion at older age than major $\beta$-thalassemics. The age range among major $\beta$-thalassemic subjects was 3-10.5 year-old, whereas in $\beta$ $\mathrm{HbE}$-thalassemic subjects was 5-13 year-old.

This study found a higher proportion of increased ALT (76\%) compared to Jaiswal et $\mathrm{al}^{19}$ who found that
$38 \%$ of major $\beta$-thalassemic patients with repeated transfusions had impaired liver function. The proportion of subjects with increased ALT increased in relation to duration of illness, which was similar to what was suggested by Modell. ${ }^{5}$ Both the $0-5$ year and the $>5$ year groups of duration of illness showed that increased ALT seemed to be related to long duration of illness, total volume of PRC transfusions, and the iron accumulation that occurred.

The proportion of subjects who had increased ALT increased with the more total volume of PRC transfusions they had gotten. This was in accordance with the study by Jaiswal et al. ${ }^{19}$ The higher proportion of subjects who had increased ALT among subjects who got total volume of PRC of $>11,397.5 \mathrm{~mL}$ was caused by higher total volume of PRC transfusions and longer duration of illness. All subjects in this group who had increased ALT also had increased TS, suggesting that iron accumulation was the cause of their impaired organ function.

The proportion of increased TS (78\%) was similar to the result of the study by Roesli ${ }^{21}$ who found that $73.44 \%$ of his subjects suffered from iron accumulation. The proportion of subjects who had increased TS was increased in relation to duration of illness. This was in accordance with Modell's statement. ${ }^{5}$ The increased proportion of subjects who had increased TS among those who had duration of illness of $>5$ years seemed to be influenced by the longer duration of illness and higher total volume of PRC transfusions. All subjects in both duration of illness groups of $0-5$ years and $>5$ years who had increased TS also had increased ALT, suggesting an iron accumulation accompanied with impaired liver organ function.

The increased proportion of subjects who had increased TS in relation with increased total volume of PRC transfusion was in accordance with the result of the Modell's study. ${ }^{5}$ Longer duration of illness and higher total volume of PRC transfusions seemed to increase the number of subjects who had increased TS among the subjects with total PRC volume of $>11,397.5 \mathrm{~mL}$.

The proportion of subjects who had increased TS did not increase among subjects with positive antiHCV. This result differed from the result of Wonke et $a^{22}$ and $\mathrm{Lau}^{23}$ studies who found increased ferritin level among thalassemic patients infected by hepatitis C. Normal level of TS was found in 2 patients, one sub- 
ject aged 3 years with duration of illness of 2 years and total volume of PRC transfusions of $5,100 \mathrm{~mL}$, and the other aged 8 years with duration of illness of 3 years and total volume of PRC transfusions of 6,445 $\mathrm{mL}$. This normal level of TS was probably caused by a relatively short duration of illness and a relatively small amount of total volume of PRC transfusions they had received.

The finding of only a small number of positive anti-HCV $(6 \%)$ in this study was different to other similar studies abroad. Jaiswal et $\mathrm{al}^{19}$ in India found that prevalence of hepatitis among thalassemic patients was 21\%, whereas Okada et al20 in Japan found a higher number, 39\%. This different result was probably caused by the different method of anti-HCV assessment used in these studies. Other probable cause is that the subjects in these studies were those who started to get their PRC transfusions after the year of 1996, the time when the blood bank started to screen donated blood for HCV. The Jaiswal study in India was conducted on subjects aged 14 months to 15 years, so that there were subjects who started to get their PRC transfusions before the year of 1996. The Okada study in Japan did not state the time of sampling and when the subjects started to get their PRC transfusions. Our finding also differed from the result of the studies of Saberi-Firoozi et all ${ }^{24}$ and Al-Fawaz et al25 who found that the prevalence of positive anti-HCV was related to duration of illness, and the study of Jaiswal ${ }^{19}$ who found that it was related to total volume of PRC transfusions. This finding was probably because our subjects were patients who started to get their PRC transfusions after the year of 1996, which meant that the donated blood was already screened for HCV so that the prevalence of hepatitis infection did not increase despite the longer duration of illness and the higher total volume of PRC transfusions. The subjects of Saberi-Faroozi and Al-Fawaz studies were not limited to those who had PRC transfusion after 1996 so that the prevalence of hepatitis $C$ was higher.

Our study still found subjects with positive anti$\mathrm{HCV}$ in spite of the blood screening. This was probably because the subjects were already infected by $\mathrm{HCV}$ before the transfusions, suggesting a source of infection in the surrounding; this warrants examination of other family members, especially the mother. Some studies reported a prevalence of intrafamilial transmission positive anti-HCV of $8.1-14.9 \%$, whereas the figure was $9 \%$ among infants born to mothers with positive HCV-RNA. ${ }^{9}$ Another probable cause was that the blood donors were in the "window period" at the time of blood screening so that no anti-HCV was found at that time.

The increased proportion of subjects who had increased ALT among subjects with increased TS suggests the role of iron accumulation in the occurrence of impaired liver function. Vullo et al ${ }^{26}$ stated that iron accumulation in organs could cause some damages to the organs. This was in accordance with the studies by $\mathrm{Lau}^{23}$ and $\mathrm{Li}$ et $\mathrm{al}^{27}$ who found that ferritin level had a role in the increment of ALT level.

The increased proportion of subjects with increased ALT among subjects with positive anti-HCV in this study was in accordance with the studies of Jaiswal et al ${ }^{19}$ and Bhatti et al. ${ }^{28}$ They found increased ALT among 63\% and 90\% thalassemic patients, respectively, who were infected by HCV.

To sum up, the proportion of increased ALT, TS, and positive anti-HCV among thalassemic patients were $76 \%, 78 \%$, and $6 \%$, respectively. Factors that seems to have a role in the increased proportion of subjects who had increased ALT and TS were 1) duration of illness, total volume of PRC transfusion, TS and anti-HCV; 2) duration of illness and total volume of PRC transfusion, respectively. Duration of illness and total volume of PRC transfusion were probably have no role in the increased proportion of subjects with positive anti-HCV.

\section{References}

1. Wahidiyat I. Thalassemia dan penanganannya. In: Wahidiyat I, Gatot D, Mangunatmadja I, editors. Perkembangan mutakhir penyakit hematologi onkologi anak. PKB IKA XXIV FKUI 1991. Jakarta: Bagian IKA FKUI; 1991. p. 109-12.

2. Hematology subdivision. Petunjuk diagnosis dan tatalaksana kasus thalassemia. Jakarta: Bagian IKA FKUI/RSCM; 1997. p. 1-20.

3. Weatherall DJ, Clegg JB. The b thalassemias. In: The thalassemia syndromes. $3^{\text {rd }}$ ed. Oxford: Blackwell Scientific Publications; 1981. p. 148-631.

4. Wirawan R, Lembar S. Hemokromatosis: klasifikasi, diagnosis dan penatalaksanaan. Maj Kedok Indon 2000;50:296-303. 
Purnamawati SP, et al: Alanine aminotransferase and hepatic iron accumulation in thalassemic patients

5. Modell CB. Management of thalassaemia major. $\mathrm{Br}$ Med Bull 1976;32:270-6.

6. Bacon BR, Brown KE. Iron metabolism and disorders of iron overload. In: Kaplowitz N, editor. Biliary diseases. $2^{\text {nd }}$ ed. Baltimore: Williams \& Wilkins; 1996. p. 349-62.

7. Bonkovsky HL, Ponka P, Bacon BR. An update on iron metabolism: summary of the fifth international conference on disorders of iron metabolism. Hepatology 1996;24:718-29.

8. Sharma BK, Bacon BR, Britton RS, Park CH, Magiera CJ, O'Neill R, et al. Prevention on hepatocyte injury and lipid peroxidation by iron chelators and a-tocopherol in isolated iron-loaded rat hepatocytes. Hepatology 1990;12:31-9.

9. Zulkarnain Z. Tinjauan multi aspek hepatitis virus $\mathrm{C}$ pada anak. In: Zulkarnain Z, Bisanto J, Pujiarto PS, Oswari $\mathrm{H}$, editors. Tinjauan komprehensif hepatitis virus pada anak. PKB IKA XLIII FKUI. Jakarta: Balai Penerbit FKUI; 2000. p. 57-72.

10. Bonkovsky HL, Banner BF, Rothman AL. Iron and chronic viral hepatitis. Hepatology 1997;25:759-68.

11. Bassett SE, Di Bisceglie AM, Bacon BR, Sharp RM, Govindarajan S, Hubbard GB, et al. Effects of iron loading on pathogenicity in hepatitis $\mathrm{C}$ virus-infected chimpanzees. Hepatology 1999;29:1884-92.

12. Desforges JF. Screening for hemochromatosis. N Engl J Med 1993;328:1616-20.

13. Powell LW, George K, McDonnell SM, Kowdley KV. Diagnosis for hemochromatosis. Ann Intern Med 1998;129:925-31.

14. Pratt DS, Kaplan MM. Evaluation of abnormal liverenzyme results in asymptomatic patients. $\mathrm{N}$ Engl J Med 2000; 342:1266-71.

15. Gruen JR, Goei VL, Capossela A, Chu TW. Hemochromatosis in children. In: Suchy FJ, editor. Liver disease in children. $1^{\text {st }}$ ed. St. Louis: Mosby; 1994. p. 773-80.

16. Kaplan MM. Laboratory tests. In: Schiff L, Schiff ER, editors. Diseases of the liver. $7^{\text {th }}$ ed. Philadelphia: JB Lippincott Company; 1993. p. 108-44.

17. Maller ES. Laboratory assessment of liver function and injury in children. In: Suchy FJ, editor. Liver disease in children. $1^{\text {st }}$ ed. St. Louis: Mosby; 1994. p. 269-93.
18. Kelly DA. Useful investigations in the assessment of liver disease. In: Diseases of the liver and biliary system in children. Oxford: Blackwell Science Ltd; 1999. p. 3-8.

19. Jaiswal SPB, Chitnis DS, Jain AK, Inamdar S, Porwal A, Jain SC. Prevalence of hepatitis viruses among multitransfused hemogenous thalassemia patients. Hepatol Research 2001;19:247-53.

20. Okada S, Taketa K, Ishikawa T, Koji T, Swe T, Win N, et al. High prevalence of hepatitis $\mathrm{C}$ in patients with thalassemia and patients with liver diseases in Myanmar (Burman) [abstract]. Acta Med Okayama 2000;54:137-8.

21. Roesli T. Hubungan peningkatan saturasi transferin, infeksi virus hepatitis $\mathrm{B}$ dan $\mathrm{C}$ dengan gangguan fungsi hati pada penderita thalassemia beta mayor [thesis]. Jakarta: Department of Clinical Pathology, Medical School, University of Indonesia; 2001.

22. Wonke B, Hoffbrand AV, Braun D, Ducheiko G. Antibody to hepatitis $\mathrm{C}$ virus in multiply transfused patients with thalassaemia major. J Clin Pathol 1990;43:638-40.

23. Lau YL. Hepatitis $C$ virus antibody in multiply transfused Chinese with thalassaemia major [abstract]. Bone Marrow Transplant 1993;12 (Suppl 1):26-8.

24. Saberi-Firoozi M, Yazdankhah S, Karbasi HT. AntiHCV seropositivity among multiply transfused patients with b-thalassaemia major in Southern Iran. Iran J Med Sci 1996;21:59-60.

25. Al-Fawaz T, Remia S. Decline in hepatitis B infection in sickle cell anaemia and $\mathrm{b}$ thalassaemia major. Arch Dis Child 1993;69:594-6.

26. Vullo R, Modell B, Georganda E. Question about iron overload and desferal. In: What is thalassaemia? $3^{\text {rd }}$ ed. Nicosia: Thalassaemia International Federation; 1995. p. 26-8.

27. Li CK, Chik KW, Lam CWK, To KF, Yu SCH, Lee V. Liver disease in transfusion dependent thalassaemia major. Arch Dis Child 2002;86:344-7.

28. Bhatti FA, Amin M, Saleem M. Prevalence of antibody to hepatitis $\mathrm{C}$ virus in Pakistani thalassaemics by practice agglutination test utility C 200 and C 22-3 viral antigen coated particles. J Pak Med Assoc 1995;45:269-71. 